[Wilkie, M. (2006). Kaupapa Maori Intervention in Post-Graduate Education: Ko te Pae Tawhiti Arumia Kia Tata: Seek to Bring the Distant Horizons Closer. New Zealand Annual Review of Education, 15, 45-63]

\section{Kaupapa Maori Intervention in Post- Graduate Education: Ko te Pae Tawhiti Arumia Kia Tata: Seek to Bring the Distant Horizons Closer ${ }^{1}$}

\section{MARGARET WILKIE}

\section{Abstract:}

Article Three of the Treaty of Waitangi promises Maori equal rights to enjoy the benefits of citizenship in Aotearoa/New Zealand, including quality education. We have had more than a century of bad news about the failure of the education system to uphold that promise. It is now, at the beginning of the 21st century, with the renaissance for Maori responding to the systemic failures by claiming and reframing the problems and implementing Maori-centred solutions, that progress is being made. Kaupapa Maori is emerging from within the Maori world itself with practical solutions that work for Maori and begin to impact positively at all levels of education, from early childhood through to postgraduate studies. This renewal has positive effects for the whole nation and potentially offers models for other minority indigenous peoples of the world to draw from and adapt for their own development.

ummarising research undertaken in 2005 that reviewed literature on Kaupapa Maori educational theory and research practices, this article describes one Kaupapa Maori intervention which impacted positively on post-graduate education for Maori nationwide. Beginning with some definitions of Kaupapa Maori itself, it moves on to describe some of the key points of Kaupapa Maori theorising in education, giving some background on the current status quo of Maori in tertiary education, before ending with a description from within the national programme for Maori and Indigenous Post-graduate advancement (MAI). It concludes with some good news for Maori at tertiary level.

\section{Margaret Wilkie}

\section{Kaupapa Maori Definitions}

Where the term Kaupapa Maori is used in educational literature, it is variously described as an educational practice, a theory, and as a research paradigm and research practice. One of the earliest writers and leaders in the field of Kaupapa Maori, educationalist Professor Graham H. Smith, described Kaupapa Maori as the "philosophy and practice of 'being Maori' that has a valid and legitimate social, political, historical, philosophical, intellectual and cultural authenticity" (Smith, 1992, p. 1). He later described Kaupapa Maori as "both a theory and transformative praxis which has been organically derived from within Maori communities" (Smith, 1997, p. 483).

Maori academics Bishop and Glynn describe "a proactive Maori political discourse termed Kaupapa Maori (Maori philosophy and principles)" (1999, p. 61). Pihama, Cram and Walker state that "Kaupapa Maori captures Maori desires to affirm Maori cultural philosophies and practices. In short, Kaupapa Maori is about being "fully Maori" and that "the essence of the Kaupapa Maori initiatives is the desire of Maori to be Maori" and to "know that being Maori is the norm. This is the core of Kaupa pa Maori: the affirmation and legitimation of being Maori" (2002, p. 30).

\section{Kaupapa Maori Theory}

Regarded by many Maori in the field of education studies as an innovator and initiating protagonist in Kaupa pa Maori theorising, Smith was the first to call for the development of a uniquely New Zealand theory to counter what he termed "racist ideologies and racist policies". He argued that "the emphasis of new right logic on individualism (Hayek, 1974) contradicts Maori concepts of collectivism such as iwi (tribe) hapu (sub-tribe) whanau (extended family) or the values implied in utu (reciprocity), manaaki (hospitality) or aroha (respectfulness)." Smith called for "analysis that can also take account of Maori cultural aspirations in relation to language, knowledge and culture evolved out of our own New Zealand context for analysing or adequately developing appropriate interventions for Maori" (1991, p. 6).

In a recent literature review of Kaupapa Maori, Pihama et al. (2002, p. 30) argue that "the intellectual validity of Kaupapa Maori has been established as a bona fide theory of transformation" and that "the term theory has been deliberately co-opted by Smith (1997) and linked to Kaupapa Maori in order to develop a counter-hegemonic practice and 
to understand the cultural constraints exemplified in critical questions such as "what counts as theory?" Smith challenges the narrow, Eurocentric interpretation of theory as it has been applied in New Zealand education (Pihama et al., 2002, p. 33). Citing Walker (1996) who "locates Kaupapa Maori in a distinctly theoretical terrain that is Maori initiated, defined, and controlled", Pihama et al. argue that "Kaupapa Maori theory has had the dual effect of providing both the theoretical 'space' to support the academic writing of Maori scholars and to be subject of critical interrogation, analysis, and application." They suggest that Kaupapa Maori has emerged as a contemporary discourse and a reality, as a theory and a praxis coming directly from Maori lived realities and experiences. Pihama et. al. cite Smith (1997), who argues that "Kaupapa Maori theory challenges the political context of unequal power relations and associated structural impediments" (2002, p. 32).

Kaupapa Maori strategies question the right of Pakeha to dominate and exclude Maori preferred interests in education, and assert the validity of Maori knowledge, language, custom and practice, and its right to continue to flourish in the land of its origin, as the tangata whenua (indigenous) culture (Smith, 1997, p. 273).

Earlier, Smith presented Kaupapa Maori as "the central organising philosophical and practical basis of contemporary Maori educational resistance" employing the deconstruction of Pakeha hegemony that disempowered Maori from, among other things, controlling their own knowledge. "Kaupapa Maori decodes the ideological interests of the dominant Pakeha society that permeate educational structures through a capture of the meanings of curriculum, pedagogy, knowledge and evaluation." Smith further presents the shift of Kaupapa Maori over time from "the domain of 'unofficial knowledge' to the legitimated domain of "official knowledge" - a shift from the marginal position of the constructed "other" to the more central position of "inclusion" (Smith, 1992, p. 2).

Pihama et al. suggest that "Kaupapa Maori theorising has ranged across a variety of educational sites and issues, critiquing specific policies imposed on Maori" (2002, p. 34). They warn that repositioning Maori as "the norm in our own constructions ... acts as a challenge to Pakeha dominance. This is clearly an issue for Kaupapa Maori implementation in mainstream institutions and settings" (p. 36).

In the academic tradition of critiquing to establish the validity or otherwise of theories, educationist Elizabeth Rata has challenged the validity of Kaupapa Maori, calling it deeply flawed, based on: the neotraditionalist assumption of two ethnically distinctive groups divided by determining cultural differences ... the assumption of a kaupapa Maori "way of knowing" that links the social practice of knowledge creation to genetic inheritance and ... that a cultural idealism approach in which "the everyday reality of social reproduction (is) replaced by the reproduction of symbolic representations." (2004, p. 3)

It is puzzling, as Rata states that "Distinctive ethnic boundaries do not exist between Maori and non-Maori", but follows this by using New Zealand Statistics collected from census returns, where great care has been taken to establish the self-identified differences in ethnicities that make up the population. Citing Chapple (2000), Rata states that the gaps between Maori and non-Maori in educational achievement and other socio-economic indicators are closing, which in itself refers to the published evidence that there is an identifiable disparity between the two ethnically distinct groups.

In the 2005 review of literature relating to Kaupapa Maori in the field of education, I have yet to find any reference to knowledge creation based on genetic inheritance - this would predicate an exclusivity to Kaupapa Maori which is far from that demonstrated in practice, as stated by Pihama et al. (2002, p. 33). "Kaupapa Maori challenges, questions and critiques Pakeha hegemony. It does not reject or exclude Pakeha culture. It is not a one-or-the-other choice." Finally, Kaupapa Maori in its early alignment with critical and feminist theory, far from resorting to "symbolic representations" of "everyday reality" attempts to bring forward the actual nature of the lived Maori experience, using an authentic and legitimate Maori voice. The searches for models drawn from Te Ao Maori have as much validity as the constructions used by theorists in the non-Maori academy to describe and explain the world.

Bishop and Glynn provide another view of Kaupapa Maori theorising which draws on post-colonial and critical theory:

Kaupapa Maori educators focus on the power relationships that exist as a result of colonialism at all levels of society and in education. What is significantly different about a kaupapa Maori approach to theorising about education is seeing that the relationship is paramount, in fact more so than the individual components of the relationship. Therefore rather than the focus for development being on either party, it is the interaction patterns that result from the relationships that is the focus. $(1999$, p. 73$)$ 


\section{Maori and New Zealand Tertiary Education}

Since the mid-1990s the tertiary sector in Aotearoa/New Zealand has been under review, with wide-reaching changes impacting the sector and its participants. The Education (Tertiary Reform) Amendment Act led to the introduction of the Tertiary Education Strategy (Ministry of Education, 2002) that set the strategic direction for the tertiary education system. At this highest policy level, there is evidence of the influence of Kaupapa Maori both in terms of structure and Maori cultural considerations. The Act formalised the establishment of the Tertiary Education Commission (TEC) to implement the strategy, and bring about other changes such as sector funding (now subject to approval of profiles for all tertiary education organisations), and the requirement for charters which have demonstrated consultation with Maori.

The Tertiary Education Strategy states: "Partnership and autonomy expressed in the Treaty of Waitangi must be given effect through the Government, Maori and the tertiary education system working together to produce success in terms meaningful to Maori" (p. 18). Strategy Two, "Te Rautaki Matauranga Maori - Contribute to the Achievement of Maori Development", is strongly influenced by the work of the Maori Tertiary Reference Group, created to advise on Maori tertiary education issues, and to be responsible for the Maori Tertiary Education Framework (MTEF) (Ministry of Education, 2003a). The MTEF was based on analysis of consultation with Maori, the Hui Taumata Matauranga, where iwi met to discuss Maori educational development, and the work of leading Maori academics and representatives of Maori stakeholders in the tertiary sector. In the words of Dr Linda Tuhiwai Smith, who chaired the Maori Tertiary Reference Group, "this Framework is an examination of how the tertiary system could work 'better' for Maori and what Maori think that means" (Ministry of Education, 2003b, preface).

The MTEF includes three visions for Maori advancement summarised by Durie (2002) in a keynote address to the Hui Taumata Matauranga in 2001:

- to live as Maori;

- to enjoy good health and a high standard of living; and

- to actively participate as citizens of the world.

The Framework also has five guiding principles for a healthy tertiary education system, drawn from Kaupapa Maori; Whakanui respect/inclusiveness; Toi Te Mana - influence/empowerment; Nga
Kawenga - responsibility; Ahu Kawanatanga - contribution/partnership; and Tino Rangatiratanga - authority/self-determination. The MTEF has seven priority areas, one of which, "Priority seven - Maori-centred Knowledge Creation" includes an overall goal for research and development within tertiary education that is of benefit to Maori.

In June 2004, the TEC released a final draft of the Strategy for the Tertiary Education Commission: Working with Maori 2004-07, and in this they state that:

Education is at the heart of what Government wants to achieve for New Zealand's sustainable social and economic development. It is at the heart of what Iwi and Maori have said they want for themselves and their future generations - one that is meaningful and relevant to meet their diverse aspirations and one that allows them to achieve their full potential. (Tertiary Education Commission, 2004, p. 8)

The Commission also states that it "recognises that achieving the outcomes envisaged for Te Rautaki Matauranga Maori requires the TEC to strengthen the tertiary education system's capability to deliver high quality tertiary education to Maori, and be accountable for that delivery" (p. 6).

\section{Maori Achievement and Participation Patterns in Tertiary Education}

Measuring the current capability of the tertiary education system in its delivery and performance for Maori is not a simple matter. To date little information of a qualitative nature is available, and quantitative data is published by several separate sources. In 2001, Maori made up almost 15 percent of New Zealand's total population. The proportion of Maori in regional populations varies, but for Maori to have equitable participation in all levels of education from early childhood to post-graduate, the participation rates nationally should be around 15 percent. The reality in the tertiary sector is a nationwide disparity of Maori participation in, and graduation from, courses of study at degree level and above.

Smith wrote of the significant disparities of Maori participation and achievement in higher education, and notes that Maori were forced to choose either to participate in Pakeha dominant institutional frameworks, where they are required to conform to the "taken for granted structures, or not participating at all" $(1992$, p. 9). While the crisis of low Maori participation in tertiary study has been alleviated in the past decade by the development of wananga, ${ }^{2}$ enrolling some 43 
percent of all Maori in tertiary study as at July 2003 (Ministry of Education, 2004a, p. 1), larger numbers of Maori continue to choose enrolment in non-Maori tertiary education institutions (TEIs) polytechnics 26 percent, universities 18 percent, colleges of education 2 percent. Very little has been published about Maori in any of these tertiary institutions.

The development of wananga has contributed to a large increase in the number of Maori students in formal tertiary education; these have almost doubled, from 32,825 in 1999 to 62,574 in 2003 (Ministry of Education, 2004a, p. 1), although half were studying at certificate level. In tertiary education, 19 percent of tauira Maori (students) studied at degree level, compared with 37 percent of all students in 2003. This disparity continues into postgraduate study, with 3 percent of all tauira Maori enrolled, as compared with 8 percent of all students (p. 2).

This pattern of under-representation of Maori in tertiary education is also reflected in the relatively low proportion of Maori who are teaching professionals in New Zealand tertiary education institutions (TEIs). To date the ethnicity of staff is not consistently reported by the TEIs, with the only reasonably reliable data available from the 1996 and 2001 Census of Population and Dwellings conducted by Statistics New Zealand. In 1996, New Zealand Maori made up only 8.4 percent of tertiary teaching professionals; in that same year 35 percent of tertiary staff were born outside of New Zealand. Five years later in 2001 the proportion of New Zealand Maori tertiary teachers had risen only slightly to 8.6 percent (Tertiary Education Commission, 2005, p. 42).

One measure of achievement is completion of qualifications. The completion rates at the end of 2002, for qualifications by Maori enrolled in tertiary education institutions in 1998, shows 36 percent at certificate level, 35 percent at diploma level, 39 percent at degree level, 42 percent at postgraduate certificate/diploma level, 50 percent at honours and masters level and 16 percent at doctorate level. The average completion rate across all levels of study for Maori students is 39 percent compared with 40 percent for all students in tertiary education institutions. (Ministry of Education, 2004b, p. 87). If the statistics are personalised: of ten students enrolling for tertiary study, only four gain qualifications within a five-year time frame. It is worth highlighting that this statistic shows there is no marked disparity in completed qualification rates between Maori and all students in tertiary education, but it does raise the question as to whether this is an acceptable outcome in view of the amount of money invested in the sector.
The Tertiary Advisory Monitoring Unit (TAMU) in the Ministry of Education releases statistics for the sector on an annual basis. The following chart represents the numbers of all Maori enrolled as PhD students during the years 1998 to 2004.

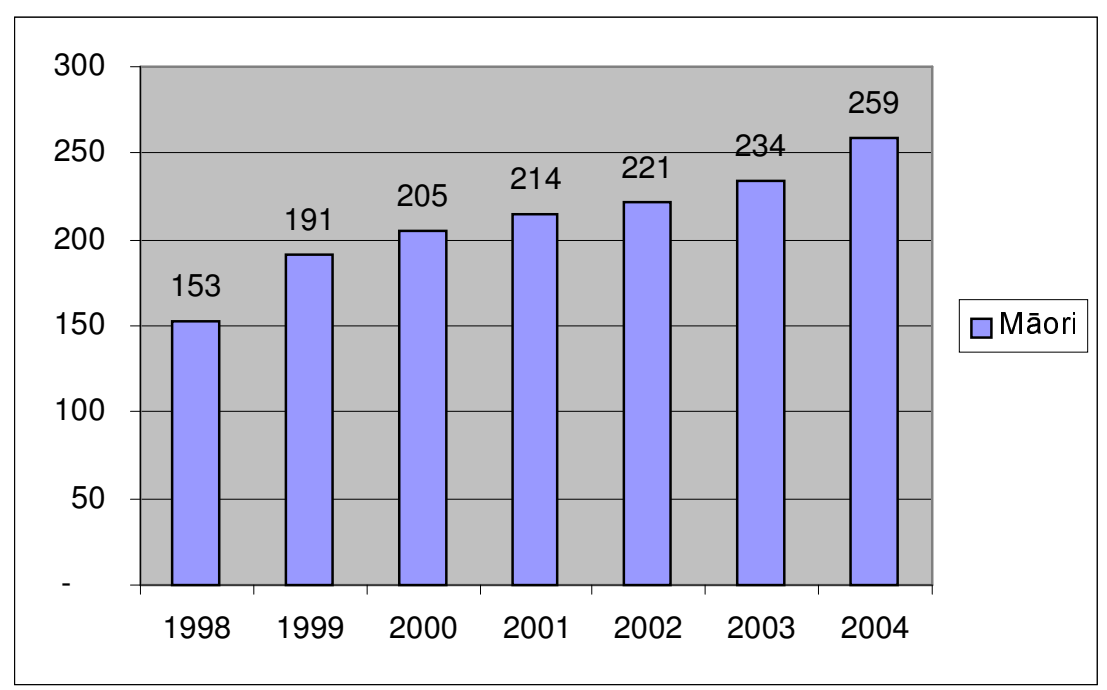

Figure 1 Domestic Maori PhDs: All Enrolments 1998-2004 Source: Ministry of Education (2005) Tertiary Education Statistics

A different set of statistics shows the numbers of Maori enrolled in PhD studies for the full years, and these numbers are slightly lower. The data for the period 2002 to 2004 are included below in Table 1. The 2005 national data will be available in mid 2006.

The table shows a steady increase in the number of enrolments for PhDs over the period, with the number of Maori as a proportion of all PhD enrolments increasing gradually. 
Kaupapa Maori Intervention in Post-Graduate Education 53

Table 1 All and Maori Enrolment in Full-Year PhD Study 2002-2004

\begin{tabular}{|c|c|c|c|}
\hline Year & All Enrolments & Maori Enrolments & Maori as \% of Total \\
\hline $\mathbf{2 0 0 2}$ & 3918 & 201 & 5.1 \\
\hline $\mathbf{2 0 0 3}$ & 4153 & 234 & 5.6 \\
\hline $\mathbf{2 0 0 4}$ & 4438 & 247 & 5.6 \\
\hline
\end{tabular}

Source: Ministry of Education (2005) Tertiary Education Statistics

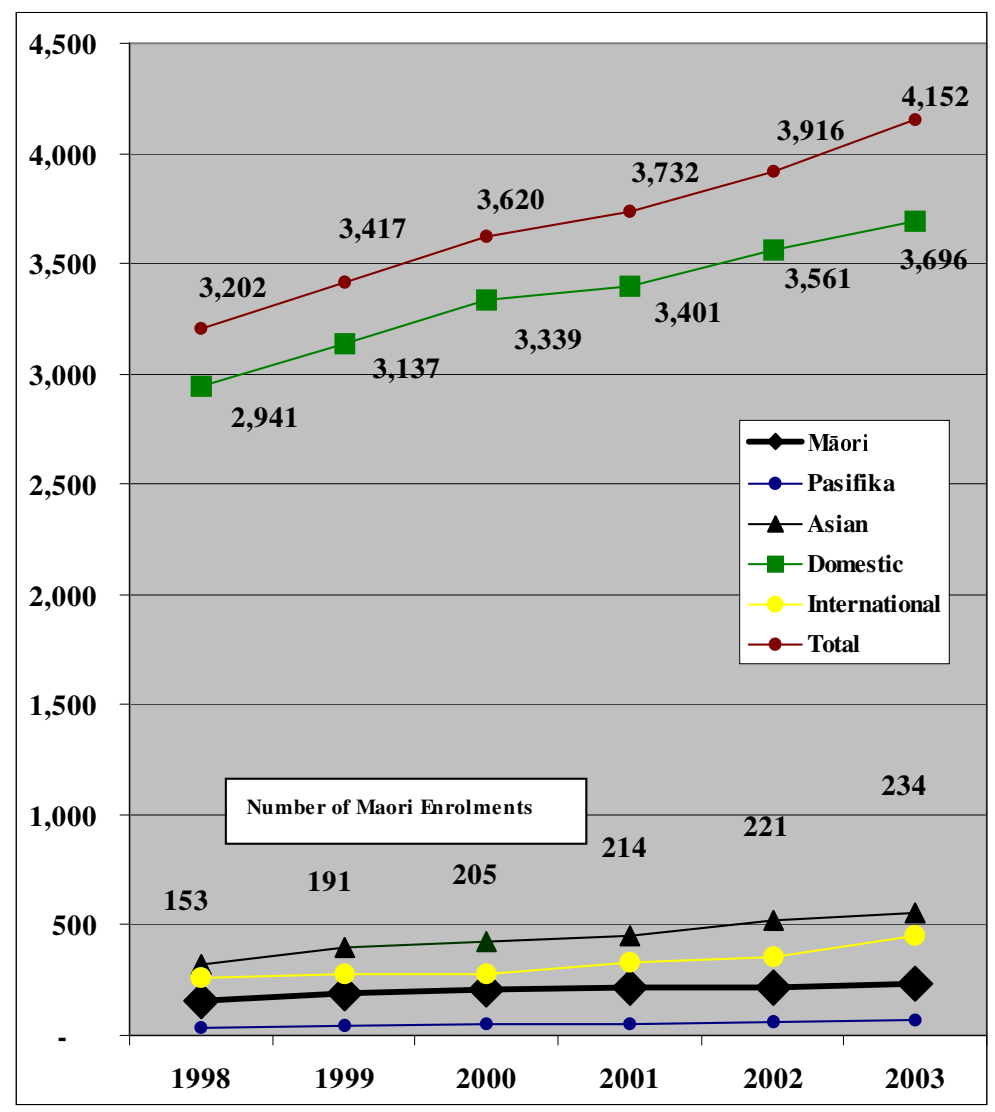

Figure 2. PhD Enrolments in New Zealand 1998-2003

Source: Ministry of Education Tertiary Statistics

\section{Margaret Wilkie}

Te Puni Kokiri (TPK - The Ministry of Maori Development) published a report on its website based on findings of a 2001 report by the New Zealand Vice Chancellors' Committee. This report shows that just over half of one percent of Maori university graduates achieved a doctoral degree:

A university degree is usually regarded as a ticket to good employment and income opportunities ... Of all university qualifications received by Maori graduates in 2000, 59\% were Bachelor degrees, $10 \%$ were Bachelor with Honours degrees, $8 \%$ were Masters degrees, $0.6 \%$ were Doctorates and 22\% were University Diplomas. (Te Puni Kokiri, 2005)

\section{Kaupapa Maori Intervention in Post-Graduate Education}

The rate of Maori participation and completion in doctoral studies has been consistently low since formal tertiary institutions first began in New Zealand. Kaupapa Maori offers a framework for intervention. Smith argues that critical analysis and consideration must be given to both cultural and structural implications when Kaupapa Maori is used as an intervention in educational crises, and gives a case study example to demonstrate the key elements or principles commonly demonstrated when Kaupapa Maori is in action (1992, pp. 27-28). These elements include; Tino Rangatiratanga (the relative autonomy principle); Taonga Tuku Iho (the cultural aspirations principle); Ako Maori (Maori teaching and learning principle); Kia Pike Ake I Nga Raruraru O Te Kainga (mediation of socio-economic impediments principle); Whanau (extended family principle) and Kaupapa (principle of collective vision). Smith concludes that "Kaupapa Maori does critically engage and challenge the taken for granted; it also mediates the debilitating effects of power and economic elements on Maori students. It attempts to create more authentic spaces for Maori to 'do their own thing' " (p. 9). These elements or principles are used to frame the case study of MAI ki Poneke (MAI in the Wellington region) presented below.

\section{Mai Ki Poneke Case Study}

The Maori and Indigenous Post Graduate support programme (MAI) grew from demand generated by the success of a Masters-level mentoring programme in the School of Education at the University of Auckland (UoA) in the 1990s. From 2002, MAI has been run as a national programme by Nga Pae o te Maramatanga: The National Institute of Research Excellence for Maori Development and Advancement (NPM), 
a Centre of Research Excellence (CoRE) which is funded by the New Zealand Tertiary Education Commission. In 2005 the national network of six MAI bases has been re-titled MAI Te Kupenga: the National Programme for Maori and Indigenous Post-graduate Advancement. A broad aim for MAI Te Kupenga

is to reach, over a five year period, a total of 500 Maori who have either completed a $\mathrm{PhD}$ or who are enrolled into a research doctoral programme. A key intention is to foster the talent pool to sustain a consciousness toward Maori development and advancement. The programme seeks to enhance the capacity and capability for intellectual leadership to assist the social, economic and cultural transformation of iwi and communities. (Nga Pae o te Maramatanga, $2005)^{3}$

The MAI programme focuses on supporting Maori doctoral students to the successful completion of their doctorates. In Wellington, MAI ki Poneke is supported within He Parekereke: Institute for Research and Development in Maori and Pacific Education at Victoria University of Wellington, and provides support for Maori and Pasifika potential and enrolled doctoral students residing in the greater Wellington region, regardless of which tertiary institution the student is, or will be, enrolled with. ${ }^{4}$

MAI as a Kaupapa Maori collaborative and inter-institutional support programme is problematic when viewed by the individual institutions of the academy, particularly when it raises questions of who owns MAI and what benefits accrue to the institutions themselves. I would argue that MAI is "owned" by the participants in the programme, and as such there is the space for relative autonomy. An increase in participation by Maori enrolled in PhD level study generates EFTS (Equivalent Full Time Student) funding to the institutions, and PhD completions contribute to the institutions' rankings in the Performance Based Research Fund (PBRF) calculations. Research funding based on these formulas replace the previous payments based on "bums on seats" and now determine the allocation of a significant part of the funds to the institutions, based on their actual research outputs. This money does not currently fund MAI ki Poneke.

\section{Tino Rangatiratanga - Relative Autonomy Principle}

Realistically there cannot be true self determination or tino rangatiratanga within the limits of the funding that comes from MAI contracts with Nga Pae o te Maramatanga, who in turn are contracted

\section{Margaret Wilkie}

to the government funding of the Tertiary Education Commission. Built into this structure, which makes MAI possible, is accountability for the use of public funds, both financially and for performance or outcomes. Pihama et al. asked, "Can real tino rangatiratanga be achieved in existing Pakeha-dominated institutional structures?" (2002, p. 40). Perhaps MAI nationally will prove to be an example of exactly this achievement.

Each MAI site operates autonomously, while linked through the national network MAI te Kupenga, resulting in constant exchanging of good practice and ideas. Within MAI ki Poneke, the annual funding is used for purposes determined by members of the group. This is done in part with a strategic "wish list" collated over several hui, and in part from responses to the requirements of the funding contract, for example to conduct hui on a regular basis throughout the year. In 2005 "MAI ki Poneke presents ... " was a series of seminars and presentations from Maori PhD students and graduates that generated the highest attendance rates for hui held monthly. Guest speakers to Maori ki Poneke hui know they are presenting because their name came up on the wish list.

\section{Taonga Tuku Iho - Cultural Aspirations Principle}

Maori are not one homogenous people, and neither are the members of MAI ki Poneke. Members come from many iwi and hapu groups with their own cultural aspirations, many passed down from tipuna or forebears, with some still directing the development of Maori people throughout the country today. At the Hui Taumata Matauranga-where all iwi were asked to look at national development for Maori education - Maori academic Dr Mason Durie (2002) put forward three visions for Maori advancement that arose from discussions in the hui, and these are pertinent to the aspirations of MAI ki Poneke members:

- To live as Maori: as an example, MAI hui follow tikanga Maori, for the correct way to proceed in hui and to be amongst other Maori doctoral students as a relief from the common experience of being "the only Maori" in their school or field of study.

- To enjoy good health and a high standard of living: PhD completion contributes to higher living standards with benefits accruing to members of the wider whanau from the improved economic situation and the role model of a family member who has achieved the doctoral degree inspiring younger generations to aspire to higher academic achievement themselves. 
- To actively participate as citizens of the world: MAI is networked globally through Nga Pae o te Maramatanga, engaging with Maori and Indigenous people studying PhDinternationally and individual doctoral students create networks to seek information from around the world pertaining to their own field of study.

\section{Ako Maori - Maori Teaching and Learning Principle}

Many aspects of the teaching and learning that occurs in the universities of the academy are "foreign" to Maori students, and this is undoubtedly part of the reason behind low Maori participation and achievement rates in higher education. Maori educationist Rose Pere (1983) re-introduced traditional learning concepts of Ako Maori to contemporary educational thinking, including learning from birth until death, so for Maori it is natural that $\mathrm{PhD}$ students range in ages from early twenties to mid sixties and beyond, although working and learning together within MAI. The important tuakana-teina (older sibling-younger sibling) relationships in learning are in evidence at MAI hui, where the roles are interchangeable and there is little or no distance between the lecturers and students or between the PhD graduates and those aspiring to move towards PhDs from their honours level degrees. The "relaxing" of the boundaries between teacher and learner, and the interchanging of those roles could be "foreign" or threatening to non-Maori members of the academy, but to Maori and other indigenous MAI ki Poneke members it is the norm.

From a Maori perspective, the structures and assumptions of the PhD-conferring academy cut across core values. For example, obtaining a PhD is an individual pursuit, whilst belonging to whanau, hapu and iwi is a collective pursuit. Where elders have the wisdom of long-held knowledge it is unsettling to report it as new knowledge, rather than the considered release and emerging of existing knowledge. The Maori values of "utu (reciprocity), manaaki (hospitality), and aroha (respectfulness)" are inherent within the structure and operations of MAI ki Poneke, and indeed within the entire national network of the MAI programme. The utu for Maori PhDs is in part the expectation and knowledge that individuals being assisted through MAI today will, as they advance and graduate from PhD studies, share their insights and advice for other MAI learners. Ideally, many will turn their expertise towards solving issues of concern to broader Maori communities. It is the newcomers and the visiting guests who may best comment on the manaakitanga practised by MAI ki Poneke, but all members can decide if aroha is upheld and nurtured there.

To be in a Maori-friendly learning environment does give Maori PhD students the space to "do our own thing" with the support of tikanga and Kaupapa Maori. For example, MAI hui are facilitated by pakeke or pukenga (in this sense, advisors/mentors) with deep knowledge of tertiary institutions and higher academic pathways. In 2005, MAI ki Poneke had ten mentors with PhDs; seven of these were Maori and a further three were Pasifika. Working their way up the poutama (stairway) are three more MAI mentors who are lecturers, currently engaged in PhD study.

\section{Kia Pike Ake I Nga Raruraru O Te Kainga - Mediation of} Socio-economic Impediments Principle

A consistent challenge for students undertaking PhD study is the financial pressure caused by the decision to curtail or suspend salary and wage earnings for the duration. In this way PhD study is definitely a juggle caused by the conflicting demands of individual study and whanau commitments. Nga Pae o te Maramatanga (NPM) who generated the MAI programme recognised this issue and created several funding opportunities, acknowledging the cost of PhD study at any life stage, including annual stipends awarded to $\mathrm{PhD}$ student applicants at each MAI site, the support for an annual MAI Doctoral Conference, and the Maori Doctoral Writing Retreat, which affords a comfortable "no interruptions, no excuses" space for intensive writing.

Recognising there is life beyond the PhD, NPM offers bridging grants for the time between $\mathrm{PhD}$ thesis submission and degree completion, to allow the production of papers and publications from the studies, and post-doctoral fellowships for those wanting to pursue research as their career pathway development. Increasingly, MAI ki Poneke shares information about other financial supports such as scholarships, and part-time work opportunities relating to research with and for Maori. On a mundane level it is somehow easier to ask for a temporary loan to get a new phone card from a fellow MAI member than it is to declare poverty on official government department application forms to get funds for the same purpose.

\section{Whanau - Extended Family Principle}

To overcome the crushing isolation of the individual path towards doctoral completion, an increasing number of Maori are turning to the 
MAI programme whanau for the tautoko (support) and advice to help them on their way. Bishop \& Glynn (1999) describe this type of collective engagement in MAI as a "whanau of interest". MAI ki Poneke hui include a process of whakawhanaungatanga (Bishop, 1996) establishing connections and relationships between all members and mentors. MAI ki Poneke members are in regular contact and supporting each other informally outside of hui, and whanau are included in activities, e.g., children and partners are able to attend the MAI hui or end of year celebrations. MAI ki Poneke extends an inclusive welcome for Maori, Pasifika and indigenous people in PhD study who live in the Wellington region and, almost inevitably, members discover previously unknown whanau, hapu and iwi links.

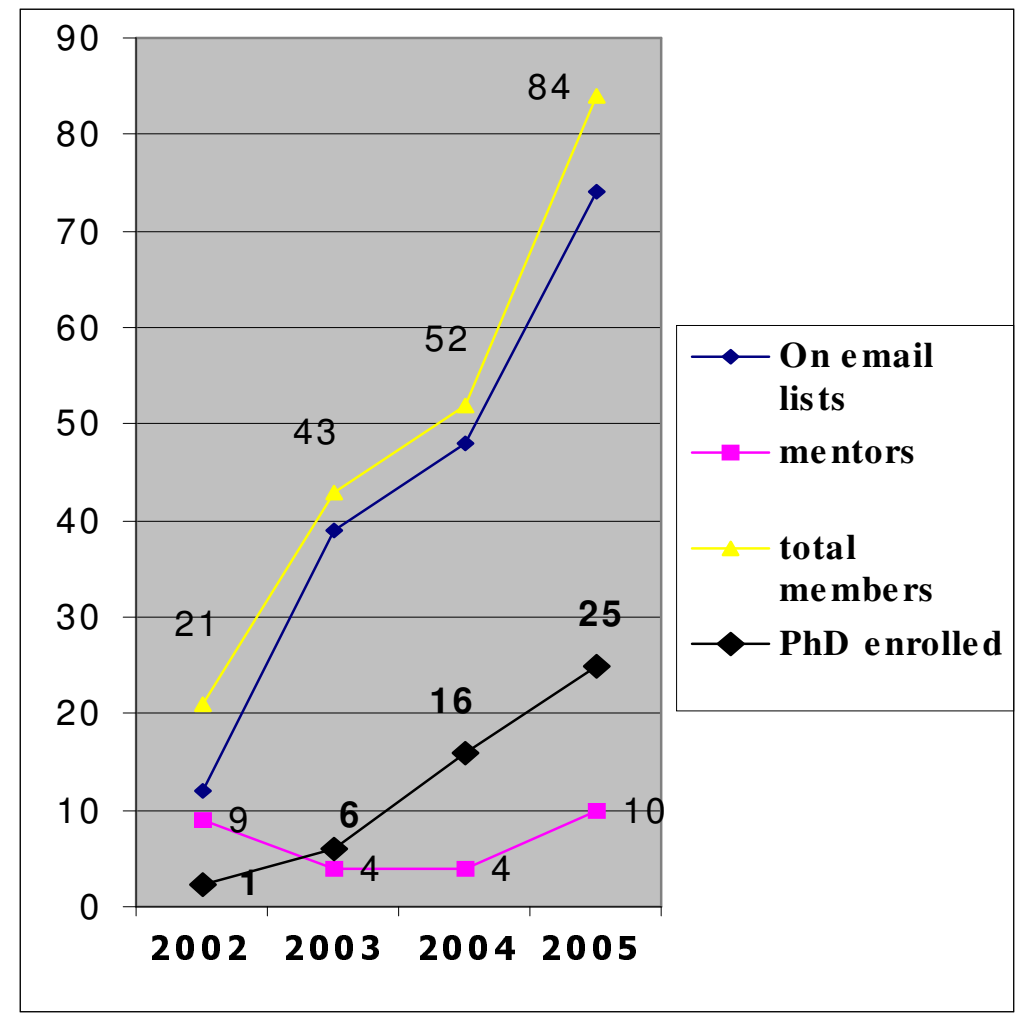

Figure 3 MAI ki Poneke Members, Mentors and PhD enrolled Source: MAI ki Poneke Digital Archive Hui Notes and Databases
In 2005, three MAI ki Poneke members submitted doctoral theses for examination and all three have now successfully completed the degree.

\section{Kaupapa - Collective Vision}

There are several statements of vision that have relevance to the MAI programme nationally. In particular, Nga Pae o te Maramatanga holds the vision of the "Transformation of New Zealand society such that Maori participate fully in all aspects of society and the economy." The vision of MAI is that it exists to encourage and support Maori and Indigenous people into PhD study, completion and graduation, and beyond that a vision first voiced by Dr G. H. Smith to create 500 Maori PhDs in five years. Given the context of recent times this vision may seem unachievable, with only three doctorates awarded to Maori in New Zealand in 1997 and 28 in 2003. In this seven-year time period 112 PhDs were awarded to Maori in New Zealand (Ministry of Education, 2005). It is perhaps the next five years that will see the blossoming of numbers of Maori completing PhDs; the evidence for this is the growing number of new enrolments in PhD study.

The increasing number of Maori graduating with doctoral degrees is good news, not only for Maori, but for New Zealand as a whole. The flow-on effects will be an increase in the pool of available Maori academics to take up tenure and offer informed supervision for more Maori students in the universities and wananga, and the consequent increased capacity for Maori research, leadership and policy development.

Notes

1. From the whakatauki in the vision statement of Nga Pae o te Maramatanga quoted in full below:

Ko te pai tawhiti arumia kia a tata

Ko te pai tata whakamaua

Kia puta i te wheiao ki te ao marama

Seek to bring the distant horizon closer

But the closer horizon, grasp it

So you may emerge from darkness into enlightenment

2. Wananga: A public tertiary institution that provides programmes with an emphasis on the application of knowledge regarding ahuatanga Maori (Maori tradition) according to tikanga Maori (Maori custom). 
(from the Glossary of Educational Terms, Ministry of Education

$<$ www.minedu.govt.nz/index.cfm?layout $=$ document\&documentid $=6$ $161 \&$ data $=1>$ )

3. More detailed information can be accessed from the MAI national website $<$ www.mai.ac.nz $>$.

4. For more information on MAI ki Poneke, see <www.vuw.ac.nz/mai>

\section{References}

Bishop, R. (1996). Collaborative research stories: Whakawhanaungatanga. Palmerston North: Dunmore Press.

Bishop, R., \& Glynn, T. (1999). Culture counts: Changing power relations in education. Palmerston North: Dunmore Press.

Durie, M. (2002). A framework for considering Maori educational advancement. Keynote address to the Hui Taumata Matauranga. Retrieved from <www.minedu.govt.nz>, February 8, 2005.

Ministry of Education. (2002). Tertiary education strategy. Wellington: Ministry of Education.

Ministry of Education. (2003a). Maori tertiary education framework. A report by the Maori Tertiary Reference Group (Draft report). Wellington: Ministry of Education.

Ministry of Education. (2003b). Maori tertiary education framework. Wellington: Ministry of Education.

Ministry of Education. (2004a). Maori in tertiary education in New Zealand in 2003. Retrieved from <www.minedu.govt.nz/goto/tertiaryanalysis>, July 2004.

Ministry of Education. (2004b). Report topic series 2003/02: Retention, completion and progression in tertiary education 2003. Wellington: Ministry of Education. Retrieved from

$<$ www.minedu.govt.nz/goto/tertiaryanalysis $>$.

Ministry of Education. (2005). Completion rates. Retrieved from $<$ www.educationcounts.edcentre.govt.nz/statistics/tertiary $>$, January 28, 2006.

Nga Pae o te Maramatanga. (2005). "MAI te Kupenga” brochure.

Pere, R. (1983). Ako: Concepts and learning in the Maori tradition. (Reprinted 1994). Wellington: Te Kohanga Reo Trust.
62 Margaret Wilkie

Pihama, L., Cram, F., \& Walker, S. (2002). Creating methodological space: A literature review of Kaupapa Maori research. Canadian Journal of Native Education, 26(1), 30-43.

Rata, E. (2004, July). Ethnic ideologies in New Zealand education: What's wrong with Kaupapa Maori? Paper presented to the Teacher Education Forum of Aotearoa New Zealand Conference (TEFANZ), Auckland College of Education.

Smith, G. H. (1991). Tomorrow's schools and the development of Maori education. Monograph 5. Auckland: The University of Auckland, International Research Institute for Maori and Indigenous Education.

Smith, G. H. (1992, November). Tane-nui-a-rangi's legacy ... propping up the sky: Kaupapa Maori as resistance and intervention. Paper presented at the New Zealand Association for Research in Education/Australia Association for Research in Education joint conference, Deakin University, Australia.

Smith, G. H. (1997). The development of kaupapa Maori: Theory and praxis. Unpublished PhD thesis, University of Auckland, Auckland.

Te Puni Kokiri. (2005). Figures retrieved from <www.tpk.govt.nz/maori/education/graddest_02.asp\#degree>, September 9, 2005.

Tertiary Education Commission (TEC). (2004). Strategy for the Tertiary Education Commission: Working with Maori 2004-07. Wellington: TEC.

Tertiary Education Commission. (2005). Report on the scope and methodology/strategic review of the tertiary education workforce. Wellington: TEC.

Wilkie, M. (2005). Kaupapa Maori research, theory and frameworks in New Zealand tertiary education: A literature review. Tihei Oreore Monograph Series Intern Reports,1(3), 267-295.

Wilkie, M. (2005, October) Nau MAI, Haere MAI: Kaupapa Maori theory, research and intervention in post-graduate education. Paper presented to MAI Doctoral Conference, Onuku Marae, Akaroa.

\section{The Author}

Margaret Wilkie (Ngati Porou, Ngapuhi) is a full-time PhD student within He Parekereke: Institute for Research and Development in Maori and Pacific Education, in the Faculty of Education at Victoria University of Wellington. She is qualified as a secondary teacher, and worked for 
16 years in a New Zealand polytechnic specialising in second chance education and Maori development. Current research interests are Maori in New Zealand polytechnics and Institutes of Technology and the application of Information Communication Technologies in tertiary education. Since 2003 she has been the part-time administrative co-ordinator for MAI ki Poneke and in 2005 was awarded a Nga Pae o te Maramatanga Doctoral Stipend for 2006 and the Philippa and Morvyn Williams Scholarship to support fieldwork for the doctoral study in 2006.

\section{Acknowledgements}

My thanks for the mentoring, advice and feedback on the drafts of this article by Dr Joanna Kidman and Dr Wally Penetito, Joint Directors of He Parekereke and Academic Coordinators of MAI ki Poneke. 